\title{
Parkinson's disease following COVID-19: causal link or chance occurrence?
}

\author{
Wei-Shan Li, Ling-Ling Chan, Yin-Xia Chao and Eng-King Tan
}

There is increasing evidence of neurological involvement in central and peripheral nervous systems in COVID-19 patients [1]. However, the association of specific neurologic syndromes with COVID-19 in some instances is unclear. Here, we reviewed published reports of "Parkinson's disease" (PD) following COVID-19 infections and discuss the potential links and challenges. We identified 3 independent reports linking PD with COVID-19 [2-4] (from pubmed search of terms "Parkinson's disease" and "COVID-19") as summarized in Table1.

All 3 case reports revealed a temporal relationship between acute COVID-19 infection and new-onset parkinsonism with intervals ranging from 10 to 32 days. None of the patients had a family history of parkinsonism, was exposed to drugs that may cause parkinsonism or reported any prodromal parkinsonian symptoms. Except for the patient reported by Méndez-Guerrero et al. [4] being critically ill and requiring mechanical ventilation, the other 2 patients had only relatively mild COVID-19 infection. There was no evidence of brain COVID-19 infection (from spinal tap) nor were the MRI brain scans abnormal, although positron emission tomography (PET) scan and dopamine transporter (DaT) scan did reveal asymmetric findings in all 3 cases. While clinical improvement was observed in all the cases, only 2 patients responded clinically to dopamine agonist or levodopa.

The authors of these reports have suggested a possible causal relationship between COVID-19 infection and new-onset parkinsonism. However, we would like

\footnotetext{
*Correspondence: gnrtek@sgh.com.sg National Neuroscience Institute, Duke NUS Medical School, Outram road Singapore 169608, Singapore
}

to draw attention to some caveats that have not received attention.

First, Cohen ME et al. [2] in their report did not specifically state if a thorough neurological examination has excluded signs of parkinsonism at the time of admission for COVID-19 infection. Since viral parkinsonism is far less common than PD [5], it is possible that these reported patients may already have preexisting PD but the symptoms/signs were unmasked by the acute viral infection.

Second, there was no neuroimaging evidence of inflammation or structural damage in basal ganglia or olfactory tract, nor evidence of COVID-19 infection in the cerebral spinal fluid (CSF). Neuroimaging involvement of thalamus, basal ganglia and substantia nigra as well as positive CSF viral markers are common findings seen in viral parkinsonism [10]. Given the normal MRI brain scans and unremarkable CSF studies in all the cases, alternative causes other than the acute COVID-19 infection should be entertained.

Interestingly, these reports [2-4] have not excluded the possibility of a chance occurrence of COVID-19 infection in patients who have undiagnosed PD. However, the asymmetric findings on PET scan or DaT scan seen in all 3 cases and a fairly good response to dopamine agonist or levodopa in cases reported by Cohen et al. and Faber et al. $[2,3]$ are in keeping with PD. Furthermore, any form of sepsis frequently exacerbates parkinsonian symptoms, especially hand tremor. The suggested association will be much stronger if there was no clinical evidence of parkinsonism on detailed examination upon admission and longer term follow up information is available to show a complete recovery or a static course of the symptoms.

Viral parkinsonism or postencephalitic parkinsonism, though rare, has been well recognized for decades 


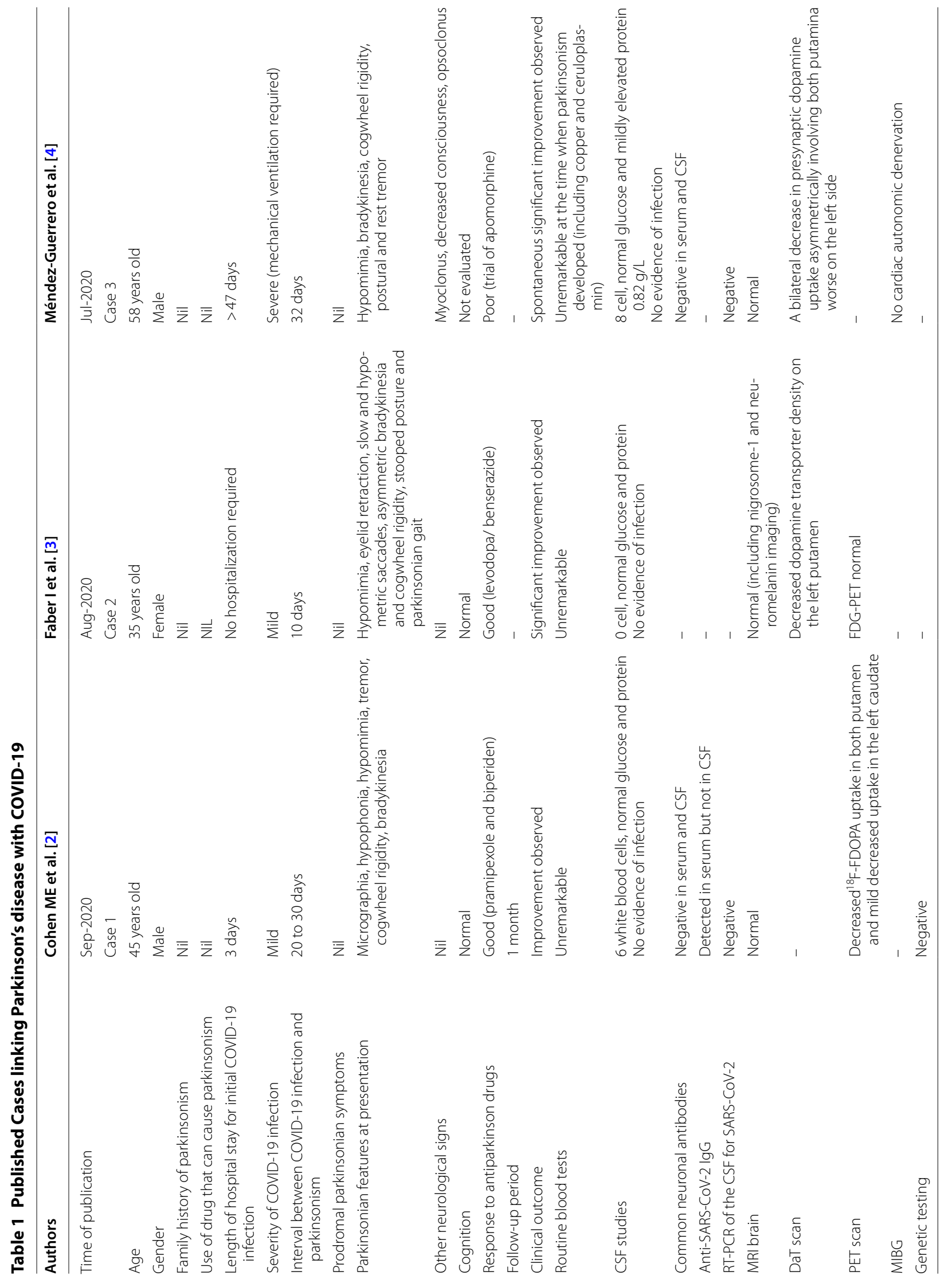


and can be caused by a variety of viruses [6]. Encephalitis lethargica, for instance, was deemed to have a very close etiologic relationship with postencephalitic parkinsonism [7] though some have argued that the etiology of postencephalitic parkinsonism may be more complex and multifactorial [8]. The exact mechanism leading to the presumed degeneration of nigrostriatal dopaminergic neurons after a viral infection is still unclear. Proposed hypotheses include virus-induced inflammation contributing to neurodegeneration [9], and "multiple hit" damage [10].

In summary, while the reports of PD following COVID-19 infection are intriguing, more concrete data are needed to support their causal link and the purported direct invasion of COVID-19 into the basal ganglia in the absence of any clinical or neuroimaging evidence of encephalitis.

\section{Acknowledgements}

Not applicable.

\section{Authors' contributions}

LWS drafted the work; CLL and CYX contributed to the writing of the manuscript; TEK contributed to the conception of the work and substantively revised the manuscript. All authors read and approved the final manuscript.

\section{Funding}

National Medical Research Council.

\section{Availability of data and materials}

Not applicable.

Ethics approval and consent to participate

Not applicable.

\section{Consent for publication}

Not applicable.

\section{Competing interests}

The authors declare that they have no competing interests.

Received: 23 November 2020 Accepted: 4 December 2020 Published online: 29 December 2020
References

1. Ellul MA, Benjamin L, Singh B, Lant S, Michael BD, Easton A, et al. Neurological associations of COVID-19. Lancet Neurol. 2020;19(9):767-83. https ://doi.org/10.1016/S1474-4422(20)30221-0 (Epub 2020 Jul 2. PMID: 32622375; PMCID: PMC7332267).

2. Cohen ME, Eichel R, Steiner-Birmanns B, Janah A, loshpa M, Bar-Shalom $R$, et al. A case of probable Parkinson's disease after SARS-CoV-2 infection. Lancet Neurol. 2020;19(10):804-5. https://doi.org/10.1016/S1474 -4422(20)30305-7 (Epub 2020 Sep 16. PMID: 32949534; PMCID: PMC7494295)

3. Faber I, Brandão PRP, Menegatti F, Bispo DDC, Maluf FB, Cardoso F. Covid19 and Parkinsonism: a non-post-encephalitic case. Mov Disord. 2020. https://doi.org/10.1002/mds.28277.

4. Méndez-Guerrero A, Laespada-García Ml, Gómez-Grande A, Ruiz-Ortiz M, Blanco-Palmero VA, Azcarate-Diaz FJ, et al. Acute hypokinetic-rigid syndrome following SARS-CoV-2 infection. Neurology. 2020. https://doi. org/10.1212/WNL.0000000000010282 (Epub ahead of print. PMID: 32641525).

5. Horvath J, Burkhard PR, Bouras C, Kövari E. Etiologies of Parkinsonism in a century-long autopsy-based cohort. Brain Pathol. 2013;23(1):28-33. https ://doi.org/10.1111/j.1750-3639.2012.00611.x.

6. Casals J, Elizan TS, Yahr MD. Postencephalitic parkinsonism—a review. J Neural Transm. 1998;105:645-76.

7. Lutters B, Foley P, Koehler PJ. The centennial lesson of encephalitis lethargica. Neurology. 2018;90(12):563-7. https://doi.org/10.1212/WNL.00000 00000005176 (PMID: 29555881).

8. Vilensky JA, Gilman S, McCall S. A historical analysis of the relationship between encephalitis lethargica and postencephalitic parkinsonism: a complex rather than a direct relationship. Mov Disord. 2010;25(9):111623. https://doi.org/10.1002/mds.22908.

9. Sadasivan S, Zanin M, O'Brien K, Schultz-Cherry S, Smeyne RJ. Induction of microglia activation after infection with the non-neurotropic A/ CA/04/2009 H1N1 influenza virus. PLoS ONE. 2015;10:e0124047.

10. Sulzer D. Multiple hit hypotheses for dopamine neuron loss in Parkinson's disease. Trends Neurosci. 2007;30(5):244-50. https://doi.org/10.1016/j. tins.2007.03.009 (Epub 2007 Apr 5 PMID: 17418429).

\section{Publisher's Note}

Springer Nature remains neutral with regard to jurisdictional claims in published maps and institutional affiliations.

\footnotetext{
Ready to submit your research? Choose BMC and benefit from:

- fast, convenient online submission

- thorough peer review by experienced researchers in your field

- rapid publication on acceptance

- support for research data, including large and complex data types

- gold Open Access which fosters wider collaboration and increased citations

- maximum visibility for your research: over $100 \mathrm{M}$ website views per year

At BMC, research is always in progress.

Learn more biomedcentral.com/submissions
} 